\title{
The Effect of Student Resilience and Self-Regulated Learning on Academic Achievement
}

\author{
Risa Cahya Maulani F Galizty ${ }^{\text {a*, Nani Sutarni }}{ }^{\mathrm{a}}$ \\ ${ }^{a}$ Faculty of Economics and Business Education, Universitas Pendidikan Indonesia, Bandung, Indonesia \\ risacmfg@upi.edu*; nanisutarni@upi.edu \\ *Corresponding author
}

\begin{tabular}{|c|c|}
\hline Article Info & ABSTRACT \\
\hline Article history: & aims to determine the effect of student resilience and self- \\
\hline Received Jun 30, 2021 & regulated learning on student academic achievement in economics \\
\hline Revised Oct 25, 2021 & subjects. The research method used is an explanatory survey using a \\
\hline Accepted Oct 26, 2021 & $\begin{array}{l}\text { questionnaire as a data collection. The population in this study were } \\
\text { students of class XI and XII of Social Science senior high school in }\end{array}$ \\
\hline Keywords: & students was taken using simple random sampling technique. The data \\
\hline Resilience & $\begin{array}{l}\text { analysis technique used is multiple linear regression analysis. The } \\
\text { results showed that resilience and self-regulated learning had an effect }\end{array}$ \\
\hline Self-Regulated Lea & on students' academic achievement in economics subjects. \\
\hline
\end{tabular}

This is an open access article under the CC BY-SA license.

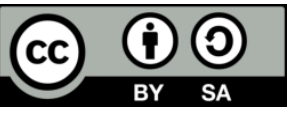

\section{Introduction}

Academic achievement to date has become a very complex problem and has been widely studied in the hope of minimizing the high unemployment rate through increasing competence to become a successful individual (He at al., 2021). This problem has many causes and has educational, social, cultural and psychological dimensions. Potential students who are weak, become a source of disturbance and discomfort in the implementation of the educational process. Academic achievement that must be achieved by students as a sign of learning success, becomes an academic challenge that must be faced by mastering material that is cognitively, socially and emotionally demanding as well as time management. Academic achievement comes from research conducted by Walberg which identifies nine key variables that influence educational achievement on student ability/previous achievement, motivation, age/developmental level, amount of teaching, teaching quality, classroom climate, home environment, peer group, and media exposure. mass that exists outside the school (Walberg et al., 1986). Walberg's theory of academic achievement, presupposes that individual psychological characteristics of students and their environment directly affect outcomes education (cognitive, affective, and attitude) (Reynolds, Arthur J.; Walberg, 1992).

Students' academic achievement depends on general cognitive abilities, such as working memory, processing speed, and relational reasoning which have been shown to play a key role in achieving educational outcomes (Geary, 2011). One of the learning theories derived from cognitive psychology is the Information Processing Theory proposed by Gagne (Nara, 
2017). According to this theory, learning is seen as a process of processing information in the human brain. The learning theory proposed by Gagne is basically a learning theory that focuses on a conditioning or environment that is conditioned to stimulate the learning process or better known as the condition of learning. Academic achievement is defined as knowledge acquired or skills developed in school subjects, usually determined by test scores or marks given by teachers, or by both (Gary D. Phye, 1996). Benjamin S. Bloom revealed that academic achievement indicators can be classified into three domains, namely the cognitive, affective, and psychomotor domains (W.S Winkel, 2012). This indicator of learning success or academic achievement for measurement, it is known as a rating scale expressed in the form of numbers and letters or from report cards obtained based on the classification of the three main aspects, namely knowledge (cognitive), attitude (affective), skills (psychomotor).

The factors that predict academic achievement require ongoing research because the student population is constantly changing and the criteria for academic success also vary from institution to institution (Obrentz \& Commander, 2012). In line with this statement, P'Pool (2012) emphasizes the importance of identifying specific factors that contribute to student academic achievement to assist educators in creating and utilizing effective teaching methods that will consequently improve academic achievement. The shift in student learning productivity is the source of the current decline in student achievement. Resilience or resilience is multi-dimensional and includes various domains such as academic, social and emotional resilience. There is a domain specification to consider when investigating robustness. Individuals can use resilience for overcoming (increasing positive control abilities, living more motivated, productive and happy), steering through (overcoming problems and pressures), bouncing back (confidence can control oneself back to normal), reaching out (meaningful experiences and learning).

The perspective of resilience theory presented by Reivich and Shatte is supported by Martin \& Marsh (2006) explaining that in the context of education, resilience is a person's ability to deal with obstacles, stress, and other difficult situations in overcoming academic problems. Resilience in the school context, namely academic resilience, is a key aspect of education. Past research has shown that resilience significantly affects school and life outcomes for students, including academic achievement (Martin \& Marsh, 2006; Waxman, H. C., Gray, J. P., \& Padrón, Y. N. (2004).

Most of the students were found to have problems in time management which hindered their studies and pre-set schedules. Organized learning is the strongest predictor of academic achievement, predicting study success and academic progress (Rytkönen et al., 2012). Selfregulated learning creates opportunities for students to manage their own resources and make all learning processes better. Zimmerman (1990) states that self-regulated learning is one of the factors that affect academic achievement.

Students will get satisfactory academic achievement when they are aware of and know effective ways of learning. Self-management relates to metacognition, motivation, and behavior that actively participates in achieving personal goals. Students who learn by selfregulated learning transform their mental abilities into academic skills and strategies. There are previous studies that report the results of his research that self-regulated learning has a positive relationship and influence on student academic achievement (Khan et al., 2020; Hakiki \& Qolby, 2019). This, the purpose of this study was to determine the effect of resilience and self-regulated learning on academic achievement of high school students in economics. 


\section{Method}

The type of research used in this research is descriptive and verification research. Based on the type of descriptive and verification research carried out through data collection in the field, the method used in this study was an explanatory survey method with simple random sampling technique. The population in this study were all public high school students throughout Cianjur Regency with a total sample of 237 students, 81 male students and 156 female high school students in class XI and XII in Cianjur regency in the academic year 2021/2022. The average age of students ranges from 17-18 years.

Analysis of the data used in this study using multiple regression analysis (Multiple Linear Regression Method) with the variables of resilience $\left(\mathrm{X}_{1}\right)$, self-regulated learning $\left(\mathrm{X}_{2}\right)$, and academic achievement (Y). A measuring tool to see how big the proportion of variation in the dependent variable is explained by all independent variables is to use the coefficient of determination $\left(\mathrm{R}^{2}\right)$ which helps explain how good our regression is (Rohmana, 2010). Hypothesis testing is done partially using the $t$ test and simultaneously using the $f$ test. The data were analyzed with the help of the SPSS version 22 program. This section is used both for articles derived from research and study results. The method section for the research paper may contain the design of steps or procedures carried out in data collection (data collection techniques) and analysis used to obtain results. Otherwise, it may contain the number of respondents used in the study. Writing a formula can use the equation by including the main source used as a reference. Articles that are of a study nature (not the results of the study) may contain a flow of thought in conducting the study, steps in data collection (information gathering), analytical techniques (if any), and criteria or reference standards used to conduct a critical and in-depth study.

\section{Results and Discussion}

Based on the results of data processing using SPSS version 22, the regression coefficient model of the resilience variable $\left(\mathrm{X}_{1}\right)$ and self-regulation $\left(\mathrm{X}_{2}\right)$ on academic achievement $(\mathrm{Y})$ is as follows.

Table 1. Results of Regression Analysis

\begin{tabular}{|c|c|c|c|c|c|}
\hline \multicolumn{6}{|c|}{ Coefficients $^{\mathbf{a}}$} \\
\hline \multirow[b]{2}{*}{ Model } & \multicolumn{2}{|c|}{ Unstandardized Coefficients } & \multirow{2}{*}{$\begin{array}{c}\text { Standardized Coefficients } \\
\text { Beta }\end{array}$} & \multirow{2}{*}{$\begin{array}{l}\text { F } \\
(\mathbf{t})\end{array}$} & \multirow[t]{2}{*}{ Sig. } \\
\hline & B & Std. Error & & & \\
\hline & & & & 62.455 & .000 \\
\hline (Constant) & 57.538 & 6.457 & & $(4.276)$ & .000 \\
\hline Resilience & .733 & .039 & .612 & 2.842 & .008 \\
\hline Self-Regulated_Learning & .547 & .150 & .278 & 1.981 & .017 \\
\hline
\end{tabular}

Referring to Table 1. The results of the Regression Analysis, the following information is obtained:

1. The Beta coefficient in the analyzed model is 0.612 on the resilience variable $\left(\mathrm{X}_{1}\right)$. This means that in this research model, the resilience variable affects the academic achievement variable by $61.2 \%$ and the remaining $58.8 \%$ is influenced by other variables outside this research. The results of the regression analysis for the second variable or self-regulation $\left(\mathrm{X}_{2}\right)$ on academic achievement $(\mathrm{Y})$ show that the result is 0.278 or has an influence of $27.8 \%$ and the remaining $72.2 \%$ is influenced by other variables outside of this study. 
2. Hypothesis testing is used to verify the truth or error of the hypothesis. The t-test is known as the partial test, which is to test the hypothesis of each independent variable on the dependent variable. Partial hypothesis testing in this study has $=0.05$ with degree of freedom $(\mathrm{df})=\mathrm{n}-\mathrm{k}=237-2=235$, so the t table is 1.652 . Based on the results of the calculations in the Table of Regression Analysis Results, it can be seen that the resilience variable has a t count value of $2.842>t$ table of 1.652 with a significant value of $0.008<0.05$ then Ho is rejected and $\mathrm{Ha}$ is accepted. Partial hypothesis testing for the self-regulation variable on academic achievement appears to have a t-count value of $1.981>t$-table of 1.652 with a significant value of $0.027<0.05$, then Ho is rejected and $\mathrm{Ha}$ is accepted. That is, the coefficient of resilience variable $\left(\mathrm{X}_{1}\right)$ and self-regulation $\left(\mathrm{X}_{2}\right)$ partially through t-test on academic achievement $(\mathrm{Y})$ can be declared significant. So, it can be concluded that the variables of resilience and self-regulation have a positive effect on students' academic achievement.

3. The calculated $\mathrm{F}$ value in this research model is 62.455 , which is greater than the $\mathrm{F}$ table of 3.04 with a significant value of 0.000 . The conclusion is to reject Ho and accept Ha, meaning that the variables of resilience and self-regulation together have an effect on student academic achievement.

\section{Effect of Resilience $\left(X_{1}\right)$ on Academic Achievement $(Y)$}

The results of the hypothesis test show that there is an effect of resilience on students' academic achievement. This is evidenced by the results of $t$ count $2.842>$ from $1.652 \mathrm{t}$ table, the significance of which is $0.008<0.05$. This means that Ho is rejected and Ha is accepted. In other words, the resilience variable has a significant effect on academic achievement. Thus, the higher the resilience, the higher the academic achievement that will be obtained by students.

Based on the presentation of the results of data analysis in the research findings, the conclusion is that resilience has an effect on student academic achievement. One of the factors that can encourage students to obtain optimal academic achievement is resilience, because high resilience will make students better able to control and create positive emotions to stay focused on doing tasks (regulation emotion), control attention and never give up when facing problems in learning. (Impulse control), optimistic and believe hard work will give success (optimism), able to identify and find various solutions to solve problems (causal analysis), have a sense of empathy, believe in being able to do many things well and be able to overcome many challenges (self-control). efficacy), likes to try new things and has the ability to be responsible and adaptable (reaching out). With the various contributions that exist in resilience for students to participate in learning and learning activities, students can achieve optimal academic achievement.

The results of this study strengthen the results of research from Hong et al. (2020) that resilience shows a positive correlation and influence on academic achievement with resilience sub-indicators such as social support, structural, relational, and self-confidence as contributors to improving student academic achievement. This research is supported by the results of research Miwha (2015) which reports that the higher the resilience, the higher the academic achievement. Resilience is the ability to utilize the positive aspects inherent in stressful situations to improve psychological outcomes such as stress and anxiety. It was found that students with high resilience because they control the emotional part have a high tendency to successfully carry out their studies with high achievement motivation despite academic disturbances or academic crises (E. K. Kim, 2019). Resilience is not an innate temperament, but rather the individual and the environment. 
In accordance with the resilience theory put forward by Reivich and Shatte who review resilience as the ability to cope with and adapt to severe events or problems that occur in life. Surviving in a depressed state, and even dealing with adversity or trauma experienced in their lives, on the contrary, people who have resilience will experience the desired achievements in their lives. People who have good resilience can understand failure is not the end of everything, and are able to take lessons from failure, and use the experience of failure to build higher aspirations (Reivich, K. \& Shatte, A. (2002). In essence, resilience has a positive meaning which is considered as confidence, optimism, and being able to see positive opportunities to achieve success so that they are able to survive in dealing with learning difficulties that exist in academic assignments.

\section{Effect of Self-Regulation $\left(X_{2}\right)$ on Academic Achievement $(Y)$}

The results of the hypothesis test show that there is an effect of self-regulation on student academic achievement. This is evidenced by the results of $t$-count $1.981>$ of $1.652 \mathrm{t}$ table, the significance of which is $0.017<0.05$. This means that Ho is rejected and Ha is accepted. In other words, the self-regulation variable has a significant effect on academic achievement. Thus, the higher the self-regulation, the higher the academic achievement that will be obtained by students.

Based on the presentation of the results of data analysis in the research findings, it can be concluded that self-regulation has an effect on academic achievement. One of the factors that can encourage students to obtain optimal academic achievement is self-regulation, because high self-regulation will make students better able to have personal functions (the ability to plan, set, and manage time to achieve learning goals), behavioral functions (evaluate himself for the progress of the work carried out and the ability to survive and enthusiasm in learning to complete learning targets) and environment function (the ability of students to choose and create physical environmental conditions to facilitate learning and have the initiative to get help from friends or others when experiencing learning difficulties) (Magno, 2010). The results of this study refer to the results of the same study Khan et al., (2020) showing that high self-regulation has a significant effect and improves student academic achievement. His findings are supported previous research. Rehman (2017) found that self-regulation is an important predictor that is positively correlated with academic achievement scores. Self-regulation is needed that is universally proven to develop positive skills and behaviors of students.

In the social cognitive theoretical framework or Social Cognitive Theory, self-regulation is explained as being specific in certain situations, i.e. learners are not expected to have balanced self-regulation in all domains. According to Bandura (1986), human functioning includes reciprocal interactions between behavior, environmental variables, as well as cognition and other personal factors. This Cognitive Information Processing Theory from B.J Zimmerman describes a process of self-regulation with individuals who activate their cognitions, behaviors and feelings systematically and are able to be oriented towards achieving learning goals. Students who learn by self-regulation transform their mental abilities into academic skills and strategies. This is done through the forethought, performance/volitional control, and self-reflection phases. In information processing theory, self-regulation is generally understood as metacognitive awareness, which includes knowledge of tasks, such as knowledge of competencies, interests, and attitudes of self, as well as procedural knowledge (Zimmerman, 1989). 


\section{Conclusion}

This study set out to provide empirical evidence and verify the conceptual arguments made by previous researchers. The results of this study indicate that resilience and selfregulation can affect students' academic achievement in economics subjects. Self-regulation and student resilience as skill sets that can be trained have been shown to positively affect student academic achievement, especially with the effective use of self-regulation. Academic resilience has a direct effect on the use of self-regulatory strategies (i.e. effort regulation, self-regulation, and time management), which affects academic achievement. The strength of indicators of resilience and self-regulation has a good impact on academic achievement. By describing several indicators that become an assessment of resilience and self-regulation of academic achievement. This research introduces a new perspective to understand the complexities of resilience and self-regulation in relation to the learning process. This finding explains the contribution of students' abilities in overcoming problems and dealing with learning difficulties that exist in academic assignments as well as developing skills and creating academic strategies that are oriented towards achieving learning goals.

\section{References}

Banarjee, P., \& Kumar, K. (2014). International Journal of Multidisciplinary Approach and Studies A Study on Self-Regulated Learning and Academic Achievement among the Science Graduate Students. International Journal of Multidisciplinary Approach \& Studies, 1(6), 329-342.

Bandura, A. (1986). Social foundations of thought and action: A social cognitive theory. APA PsychNet. https://psycnet.apa.org/record/1985-98423-000

E. K. Kim, J. Y. Y. \& J. L. L. (2019). The effect of clinical practice transitional shock and resilience on academic burnout of nursing students. The Journal of Learner-Centered Curriculum and Instruction, 19(20), 319-336.

Gary D. Phye. (1996). Handbook of Classroom Assessment Learning Achievement and Adjustment. In Handbook of Classroom Assessment. Elsevier.

Geary, D. C. (2011). Consequences, characteristics, and causes of mathematical learning disabilities and persistent low achievement in mathematics. Journal of Developmental and Behavioral Pediatrics, 32(3), 250-263.

Hakiki, T., \& Qolby, A. R. C. (2019). The Effect of Self-Regulated Learning on Academic Achievement Among Hafiz Students. 197-200.

He, X., at al. (2021). IQ, grit, and academic achievement: Evidence from rural China. International Journal of Educational Development

Hong, S.-H., Kim, J.-S., Ju, D.-B., \& Author, C. (2020). The Effect of Resilience on Academic Stress and Academic Achievement in Nursing Students. Journal of the Korea Convergence Society, 11(9), 443-450. 
Khan, Y. M., Shah, M. H., \& Sahibzada, H. E. (2020). Impact of self-regulated learning behavior on the academic achievement of university students. FWU Journal of Social Sciences, 14(2), 117-130.

Magno, C. (2010). Assessing Academic Self-Regulated Learning among Filipino College Students: The Factor Structure and Item Fit. The International Journal of Educational and Psychological Assessment, 5.

Martin, A. J., \& Marsh, H. W. (2006a). Academic resilience and its psychological and educational correlates: A construct validity approach. Psychology in the Schools, 43(3), 267-281.

Martin, A. J., \& Marsh, H. W. (2006b). Academic resilience and its psychological and educational correlates: A construct validity approach. Psychology in the Schools, 43(3), 267-281.

Miwha Noh, Mijeong Heo, Y. S. C. (2015). The Influences of Parenting Attitudes on Adolescents School Adjustment: Mediating Effects of Ego Resilience and Care. Journal of Korean Home Management Association, 33(2), 119-134.

Nara, E. S. \& H. (2017). Teori Belajar dan Pembelajaran (A. Jamludin (Ed.); 3rd ed.). Ghalia Indonesia.

Obrentz, S. B., \& Commander, N. (2012). Predictors of science success: The impact of motivation and learning strategies on college chemistry performance. Dissertation Abstracts International Section A: Humanities and Social Sciences.

P'Pool, K. B. (2012). Using Dweck's Theory of Motivation to Determine How a Student's View of Intelligence Affects Their Overall Academic Achievement. http://digitalcommons.wku.edu/theses\%0Ahttp://digitalcommons.wku.edu/theses/1 214

Rehman, U. Ur. (2018). D O Web-based Pedagogical In, Promote Self-regulated Learning in University Students? A Case Study of Learning Management System in Pakistan. International Technology, Education and Development Conference.

Reivich, K. \& Shatte, A. (2002). The resilience factor. New York Broadway Books. References-Scientif Research Publishing. (n.d.).

Reynolds, Arthur J.; Walberg, H. J. (1992). ERIC- EJ452052. A Process Model of Mathematics Achievement and Attitude., Journal for Research in Mathematics Education

Rohmana. (2010). Ekonometrika: Teori dan Aplikasi Eviews. Laboratorium Pendidikan Ekonomi dan Koperasi UPI.

Rytkönen, H., Parpala, A., Lindblom-Ylänne, S., Virtanen, V., \& Postareff, L. (2012). Factors affecting bioscience students' academic achievement. Instructional Science, 40(2), 241-256. 
W.S Winkel. (2012). Psikologi Pengajaran. Media Abadi. https://perpustakaan.iahntp.ac.id/index.php?p=show_detail\&id=3093

Walberg, H. J., Fraser, B. J., Welch, W. W., \& Walberg, H. J. (1986). A test of a model of educational productivity among senior high school students. Journal of Educational Research, 79(3), 133-139.

Waxman, H. C., Gray, J. P., \& Padrón, Y. N. (Eds.) (2004). Educational Resiliency Student, Teacher, and School Perspectives. Greenwich, CT Information Age. - References Scientific Research Publishing. (n.d.).

Zimmerman, B. J. (1989). A Social Cognitive View of Self-Regulated Academic Learning. Journal of Educational Psychology, 81(3), 329-339.

Zimmerman, B. J. (1990). Self-Regulated Learning and Academic Achievement: An Overview. Educational Psychologist, 25(1), 3-17. 